Vergleichende Länderkunde

Von Alfred Hettner. Band 3: Die Gewässer des Festlandes; Die Klimate der Erde. Pp. viii + 202. 740 gold marks. Band 4: Die Pflanzenwelt; Die Tierwelt; Die Menschheit; Die Erdräume. Pp. $\mathrm{x}+347$. 13 gold marks. (Leipzig und Berlin : B. G. Teubner, 1934-1935.)

THE two concluding volumes of Prof. Hettner's treatise on physical geography adhere to the principles laid down in vol. 1 and, while he deals with the continental areas in particular, he includes also the oceanic islands but excludes the oceans themselves. In some respects it is to be regretted that this omission has been considered desirable, for the complete work is one of considerable value, and its usefulness would have been enhanced by the inclusion of a section on oceanography.

Vol. 3 is divided into two sections, the first devoted to a discussion of the hydrosphere, in a limited sense and excluding the oceans. Under this head the author deals with snow and ice, springs, rivers and lakes. The second section consists of an excellent and comprehensive treatment of climatology, concluding with a regional discussion of the subject.

The final volume, in which the author deals with the geography of plants and animals together with a brief discussion of human geography, is probably the most interesting part of the entire work. It is to the final section in particular that the title of Prof. Hettner's book most aptly applies, and it is to be regretted that this section could not have been considerably expanded.

As a whole, the four volumes provide an exceedingly useful text-book, which should appeal to more advanced students of geography, and which covers approximately the same ground as de Martonne's "Traité de Géographie Physique".

\section{Primitives and the Supernatural}

By Lucien Lévy-Bruhl. Authorized translation by Lilian A. Clare. Pp. 405. (London: George Allen and Unwin, Ltd., 1936.) 18s, net.

M. LÉvy-BRuHL here adds to his previous studies of the primitive mind an examination of its reactions when confronted with the supernatural. As is well known, in his conception, the working of the primitive mind is so far removed from the logic of developed reasoning as to warrant regarding its processes as belonging to a different order. It has no conception of the world of abstract thought, of causation, of categories and the like. Its cosmos is unpredictable and unstable; it is a realm under the control of spirits, both good and evil, who are to be propitiated and if possible controlled. In these conditions it seems difficult to draw the line between normal and supernormal, natural and supernatural. M. LévyBruhl, whose knowledge of the literature of the subject is stupendous, here passes in review the ceremonies and rites, and the beliefs and customs relating to omens, amulets, ancestor worship, purification and the like, whereby primitive man has endeavoured to secure that the course of events either shall turn to his advantage or at least not be to his detriment.

\section{Tabulæ Biologicæ Periodicæ}

Herausgegeben von C. Oppenheimer und L. Pincussen. Band 4, Nr. 4 (= Tabulæ Biologicæ, Band 10, Nr. 4). Pp. 289-388. Complete vol., 55 gold marks. Band 5, Nr. I (= Tabulæ Biologicæ, Band 11, Nr. 1). Pp. 144. Band 5, Nr. 2 (= Tabulæ Biologicæ, Band 11, Nr. 2). Pp. 145-224. Complete vol., 55 gold marks. (Den Haag: W. Junk, 1935.)

The data given in these parts of Tabulæ Biologicæ Periodicæ are arranged as in the previous volumes. The fourth part of vol. 4 contains the concluding part of an article by Th. A. Maass on the biology and toxicology of chemical substances used in war; it also contains the index to the volume. K. Boresch contributes articles on the mineral content of plants, the first in vol. 4 and the second in vol. 5 (No. 1 and 2). The most important contribution to vol. 5 is a long article on allergy (or sensitiveness to proteins foreign to the body) by Th. A. Maass, whilst O. Reitz sum. marises our knowledge of heavy water.

\section{Practical Biology for Medical Students}

By C. J. Wallis. Pp. xii +247 . (London : William Heinemann (Medical Books), Ltd., 1936.) 12s. $6 d$. net.

ThIs laboratory manual gives detailed practical instructions to students of biology for first medical examinations and also supplies additional matter in order that it may satisfy the Higher School Certificate examinations in the subject. An unusual but useful feature in such a book is a separate section on elementary biochemistry.

Those diagrams which are not borrowed from other sources tend to be rather crude, and in places, if not misleading, then of little practical value to the student.

The book should prove useful to the teacher of biology. Since a theoretical text-book would be necessary for a student taking a course such as is provided by this book, its high price is unfortunate.

\section{The Identity Theory}

By Blamey Stevens. Second edition, revised and amplified. Pp. xvi +252. (Manchester: Sherratt and Hughes, 1936.) 12s. $6 d$.

THE object of this book is to build up a complete system of mathematical physics on a basis that is very different from that currently accepted. The fundamental assumptions are that inertia, time and space are each complete measurements of the same thing, and that by expressing this identity we get the laws of physics. For example, the space-time identity leads at once to the result that the observed velocity of light is independent of the motion of the observer, the fundamental postulate of relativity. Other identities lead to Maxwell's electromagnetic equations, Newton's laws of motion and a theory of relativity. The later chapters deal with radiation and the quantum theory. Whatever may be thought of the author's conclusions, he shows considerable knowledge of physics and mathematics. 